\title{
Synthesis and characterization of alternating fluorene-thiophene copolymers bearing ethylene glycol side-chains
}

\author{
Elisabeth Ziegler • Andreas Pein • Achim Fischereder • \\ Gregor Trimmel
}

Received: 19 May 2010/Accepted: 11 December 2010/Published online: 25 January 2011

(C) The Author(s) 2011. This article is published with open access at Springerlink.com

\begin{abstract}
New alternating fluorene-thiophene copolymers are introduced bearing polar ethylene glycolcarboxylate functionalities on the thiophene ring to achieve enhanced solubility in polar solvents. Suzuki polycondensation was applied to synthesize a set of three polymers with differing lengths of the ethylene glycol side-chains. The polymers are thermally stable up to temperatures of $300{ }^{\circ} \mathrm{C}$. Solutions of the polymers in $\mathrm{CHCl}_{3}$ show an absorption maximum at approximately $397 \mathrm{~nm}$ and a luminescence maximum of $472 \mathrm{~nm}$ in solutions with quantum yield of $30 \%$. The highest occupied molecular orbital (HOMO) and lowest unoccupied molecular orbital (LUMO) levels have been determined to be at -5.7 and $-2.6 \mathrm{eV}$, respectively.
\end{abstract}

Keywords Conjugated polymers - Luminescence · One-pot synthesis - Optical properties · Polycondensation

\section{Introduction}

During the last two decades, conjugated polymers have been in the focus of polymer and materials scientists due to their interesting chemical and physical properties and their various applications in the area of organic electronics [1, 2], e.g., in organic light-emitting devices (OLEDs) [3, 4], organic thin-film transistors [5], sensor applications [6], and polymer photovoltaics [7, 8]. Among the broad

\footnotetext{
E. Ziegler · A. Pein · A. Fischereder · G. Trimmel ( $ه)$ Institute for Chemistry and Technology of Materials (ICTM) and Christian Doppler Laboratory for Nanocomposite Solar Cells, Graz University of Technology, Stremayrgasse 9, 8010 Graz, Austria

e-mail: gregor.trimmel@tugraz.at
}

variety of polymers synthesized to date, polyfluorenes are some of the most prominent polymers, and because of their blue emission and high fluorescence quantum yield combined with good thermal and chemical stability, they are especially interesting materials for OLEDs [9-13]. In addition, copolymers of fluorenes with other arylene monomers are easily accessible, and the band gap and other electrooptical properties can be tuned over a broad range by the choice of proper co-monomers [3, 14-17]. In this regard, fluorene-arylene copolymers are discussed in all aspects of applications for conjugated polymers [18-21].

Suzuki polycondensation (SPC) is one of the methods of choice for synthesis of polyfluorenes and copolymers, as it is a versatile and simple method to obtain polyarylenes and especially alternating copolymers [4]. A comprehensive overview on the occasion of the 20th anniversary of SPC was published by Sakamoto et al. [22] last year.

State-of-the-art organic electronic devices very often exhibit a multilayer structure with different organic layers stacked on each other, e.g., hole conducting layers, lightemitting layer, etc. Consequently, it is necessary to deposit different organic layers on top of each other. To keep an all solution-based process for device assembly, use of orthogonal solvents is advantageous, which in turn needs polymers with orthogonal solubilities. In contrast to the electrooptical properties of fluorene copolymers, which are primarily determined by the chemical structure of the backbone, the solubility of these polymers is mainly a result of the chosen side-chain, e.g., the introduction of long alkyl and branched side-chains for apolar solvents, or ionic side-groups for protic and polar solvents [23, 24].

In this contribution we focus on the synthesis of a set of new alternating 9,9-dioctylfluorene thiophene copolymers with carboxy(ethylene glycol) side-chains on the thiophene ring to obtain polymers possessing all the positive 
optoelectronic characteristics of such polymers and in addition enhanced solubility in polar solvents. Starting from 2,5-dibromothiophene-3-carboxylic acid, the monomers were prepared by esterification using ethyl-ethylene glycol, ethyl-bisethylene glycol, as well as ethyl-trisethylene glycol as alcohols. The polymers were characterized by nuclear magnetic resonance (NMR) spectroscopy, Fouriertransform infrared (FTIR) spectroscopy, thermal analysis, and gel permeation chromatography (GPC). In addition, their solubility was investigated using a set of solvents with different polarity indices. The optical and electrochemical properties were analyzed by optical absorption and emission spectroscopy, as well as by cyclic voltammetry.

\section{Results and discussion}

\section{Synthesis and characterization}

The general synthetic routes towards the monomers are outlined in Scheme 1. The new ethylene glycol 2,5-dibromothiophene-3-carboxylate monomers, 2-ethoxyethyl 2,5-dibromothiophene-3-carboxylate (1), 2-(2-ethoxyethoxy)ethyl 2,5-dibromothiophene-3-carboxylate (2), and 2-[2-(2-ethoxyethoxy)ethoxy]ethyl 2,5-dibromothiophene3-carboxylate (3) were synthesized following a literature method [25]. After bromination of thiophene-3-carboxylic acid (4) with $\mathrm{Br}_{2}$, the intermediate 2,5-dibromothiophene3-carboxylic acid (5) was reacted with oxalylchloride. Reaction of the acid chloride (6) with the corresponding ethylene glycol monoethylether and pyridine as base afforded $\mathbf{1}(38 \%), \mathbf{2}(36 \%)$, and $\mathbf{3}(35 \%)$. The chemical structures were verified by ${ }^{1} \mathrm{H}$ NMR and ${ }^{13} \mathrm{C}$ NMR spectroscopy.

For the synthesis of the polymers poly-[9,9-dioctylfluorene-alt-(2-ethoxyethyl thiophene-3-carboxylate)] (7), poly-[9,9-dioctylfluorene-alt-[2-(2-ethoxyethoxy)ethyl thiophene-3-carboxylate]] (8), and poly-[9,9-dioctylfluorenealt-[2-[2-(2-ethoxyethoxy)ethoxy]ethyl thiophene-3-carboxylate]] (9), a general Suzuki coupling polymerization was applied, as shown in Scheme 2 [26]. Polymer 7 was synthesized using $\mathbf{1}$ and 9,9-dioctylfluorene-2,7-bis(trimethylborate) (10) and tetrakis(triphenylphospine)palladium $(0)\left[\mathrm{Pd}\left(\mathrm{PPh}_{3}\right)_{4}\right]$ as catalyst in a mixture of toluene and aqueous sodium carbonate solution $(2 \mathrm{M})$ at $85^{\circ} \mathrm{C}$ for 2 days. Polymers 8 and $\mathbf{9}$ were prepared by the same procedure, using $\mathbf{2}$ and $\mathbf{3}$, respectively. All three polymers were obtained in good yields of $73-90 \%$ as green powders.

The chemical structures were verified by ${ }^{1} \mathrm{H}$ NMR and IR spectroscopy. The number-average molecular weights $\left(M_{\mathrm{n}}\right)$ of polymers $\mathbf{7}, \mathbf{8}$, and $\mathbf{9}$ were determined by GPC using a polystyrene standard to be $8,600 \mathrm{~g} / \mathrm{mol}$

\section{Scheme 1}
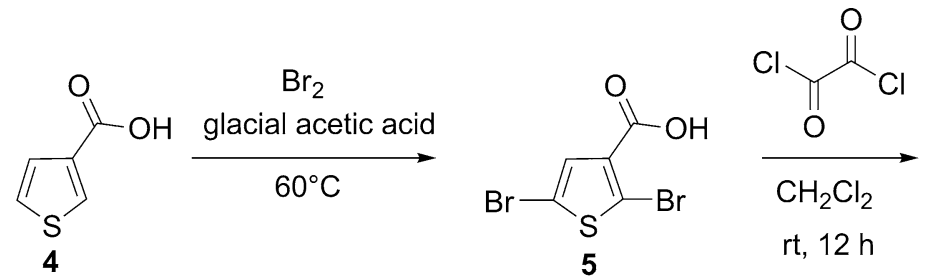<smiles>O=C(Cl)c1cc(Br)sc1Br</smiles>

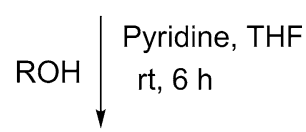<smiles>[R]=CCOCCOCCOCCOCC</smiles><smiles>[R]OC(=O)c1cc(Br)sc1Br</smiles>

Scheme 2
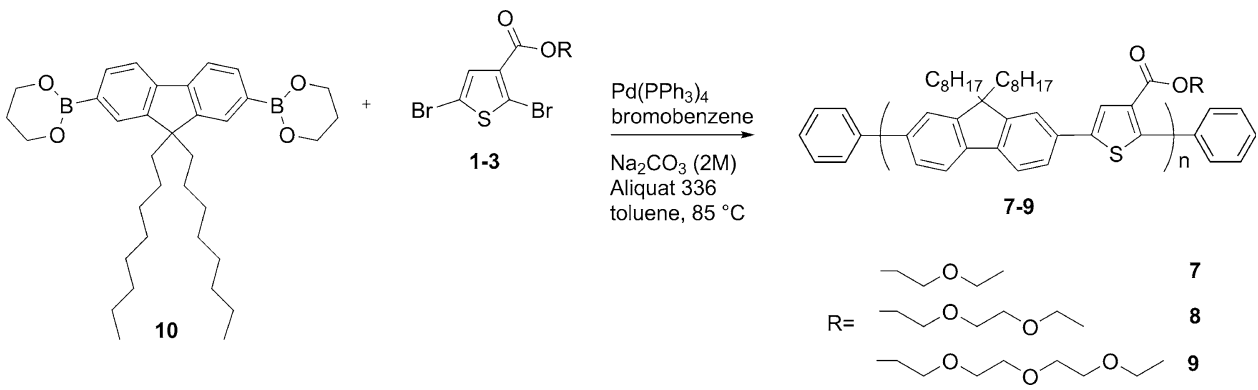
Table 1 Number-average $\left(M_{\mathrm{n}}\right)$ and weight-average $\left(M_{\mathrm{w}}\right)$ molecular weights of polymers $\mathbf{7 - 9}$

\begin{tabular}{lcll}
\hline & $M_{\mathrm{n}}(\mathrm{g} / \mathrm{mol})$ & $M_{\mathrm{w}}(\mathrm{g} / \mathrm{mol})$ & $M_{\mathrm{w}} / M_{\mathrm{n}}$ \\
\hline $\mathbf{7}$ & 8,600 & 14,600 & 1.7 \\
$\mathbf{7}^{\mathrm{a}}$ & 17,200 & 21,300 & 1.2 \\
$\mathbf{8}$ & 9,900 & 16,700 & 1.7 \\
$\mathbf{9}$ & 10,200 & 22,400 & 2.2 \\
\hline
\end{tabular}

${ }^{a}$ After acetone Soxhlet extraction

$\left(M_{\mathrm{w}} / M_{\mathrm{n}}=1.7\right), \quad 9,900 \mathrm{~g} / \mathrm{mol} \quad\left(M_{\mathrm{w}} / M_{\mathrm{n}}=1.7\right), \quad$ and $10,200 \mathrm{~g} / \mathrm{mol} \quad\left(M_{\mathrm{w}} / M_{\mathrm{n}}=2.2\right)$, respectively. The GPC results are summarized in Table 1 . In the case of $\mathbf{7}$, lowmolecular-weight oligomers can be removed using Soxhlet extraction with acetone as solvent, resulting in a polymer with $M_{\mathrm{n}}=17,200 \mathrm{~g} / \mathrm{mol}$. In addition the molecular weight distribution is narrowed down to a value $M_{\mathrm{w}} / M_{\mathrm{n}}$ of 1.2 . This procedure cannot be applied for $\mathbf{8}$ and $\mathbf{9}$, as both polymers are fairly soluble in hot acetone.

The thermal stability of the polymers was evaluated under helium atmosphere by thermogravimetric analysis (TGA). The polymers possess good thermal stability as there was no weight loss detectable until $300{ }^{\circ} \mathrm{C}$, as shown in Fig. 1. Polymer 7 showed $5 \%$ weight loss at $373{ }^{\circ} \mathrm{C}(8$ at $357^{\circ} \mathrm{C}$ and 9 at $387^{\circ} \mathrm{C}$ ), which is caused by a decomposition of the side-groups. The thermally induced phasetransition behavior of the polymers was investigated with differential scanning calorimetry (DSC) in nitrogen atmosphere, but only very weak signals could be detected. Additionally the signals weakened with increasing length of the polyglycol side-group. This is a sign for decreasing crystallinity with increasing length. All three polymers showed one endothermal peak at heating at around $100{ }^{\circ} \mathrm{C}$ $\left(7119{ }^{\circ} \mathrm{C}, 895^{\circ} \mathrm{C}, 992^{\circ} \mathrm{C}\right)$.

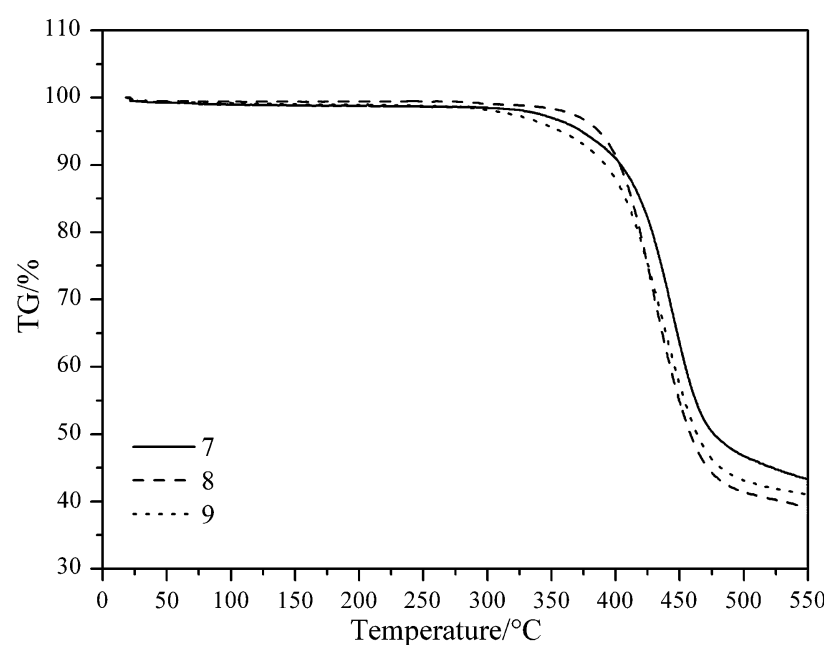

Fig. 1 Thermogravimetric analysis of polymers 7-9
Table 2 Solubility of polymers 7-9 in solvents of different polarity

\begin{tabular}{lllll}
\hline & Polarity index & 7 & $\mathbf{8}$ & $\mathbf{9}$ \\
\hline$n$-Hexane & 0 & \pm & \pm & \pm \\
Toluene & 2.3 & ++ & ++ & ++ \\
Chlorobenzene & $2.7^{\mathrm{b}}$ & ++ & ++ & ++ \\
Dichlorobenzene & $2.7^{\mathrm{b}}$ & ++ & ++ & ++ \\
$\mathrm{CH}_{2} \mathrm{Cl}_{2}$ & 3.4 & ++ & ++ & ++ \\
$\mathrm{CHCl}_{3}$ & $3.4-4.4$ & ++ & ++ & ++ \\
$\mathrm{THF}$ & 4.2 & ++ & ++ & ++ \\
Ethyl acetate & 4.3 & ++ & ++ & ++ \\
Isopropyl alcohol & 4.3 & - & \pm & \pm \\
Cyclohexanone & 4.5 & ++ & ++ & ++ \\
Ethanol & 5.2 & - & \pm & \pm \\
Acetone & 5.4 & - & + & + \\
Acetonitrile & 6.2 & - & - & - \\
DMF & 6.4 & + & + & + \\
DMSO & 6.5 & \pm & \pm & \pm \\
Methanol & 6.6 & - & - & - \\
$\mathrm{H}_{2} \mathrm{O}$ & 9 & - & - & - \\
\hline
\end{tabular}

a According to Snyder, ${ }^{\mathrm{b}}$ according to Burdick and Jackson

++ , soluble at room temperature; + , soluble at heating; \pm , partly soluble; -, insoluble

DMSO, dimethyl sulfoxide

The glycol side-groups should lead to better solubility in polar solvents. Therefore, we investigated the solubility of polymers 7, 8, and $\mathbf{9}$ in solvents of different polarities. For these experiments, $2 \mathrm{mg}$ polymer was mixed with $1 \mathrm{~cm}^{3}$ solvent, and, if the polymer was not dissolved at ambient temperature, heated to the boiling point of the solvent. The results are summarized in Table 2. The solvents are listed according to the polarity index of Snyder [27] with two exceptions; for chlorobenzene and dichlorobenzene, the values were taken from Burdick and Jackson [28]. All three polymers were well soluble in apolar solvents such as toluene (polarity index 2.3), as well as in "standard" solvents such as methylene chloride (3.4), chloroform (3.4-4.4), tetrahydrofuran (THF) (4.2), and cyclohexanone (4.5). As expected, the polymers with longer polyglycol side-group ( $\mathbf{8}$ and 9 ) showed better solubility in polar as well as protic solvents. Both polymers $\mathbf{8}$ and $\mathbf{9}$ were soluble in hot acetone, and partly soluble in hot ethanol and isopropyl alcohol. Remarkably, all three polymers were soluble in hot dimethylformamide (DMF) (6.4).

\section{Optical properties}

UV-Vis absorption and photoluminescence (PL) emission spectra of the polymers were measured both in solution $\left(\mathrm{CHCl}_{3}\right)$ and as thin film. All three polymers gave practically identical spectra, as shown in Fig. 2. In solution they 

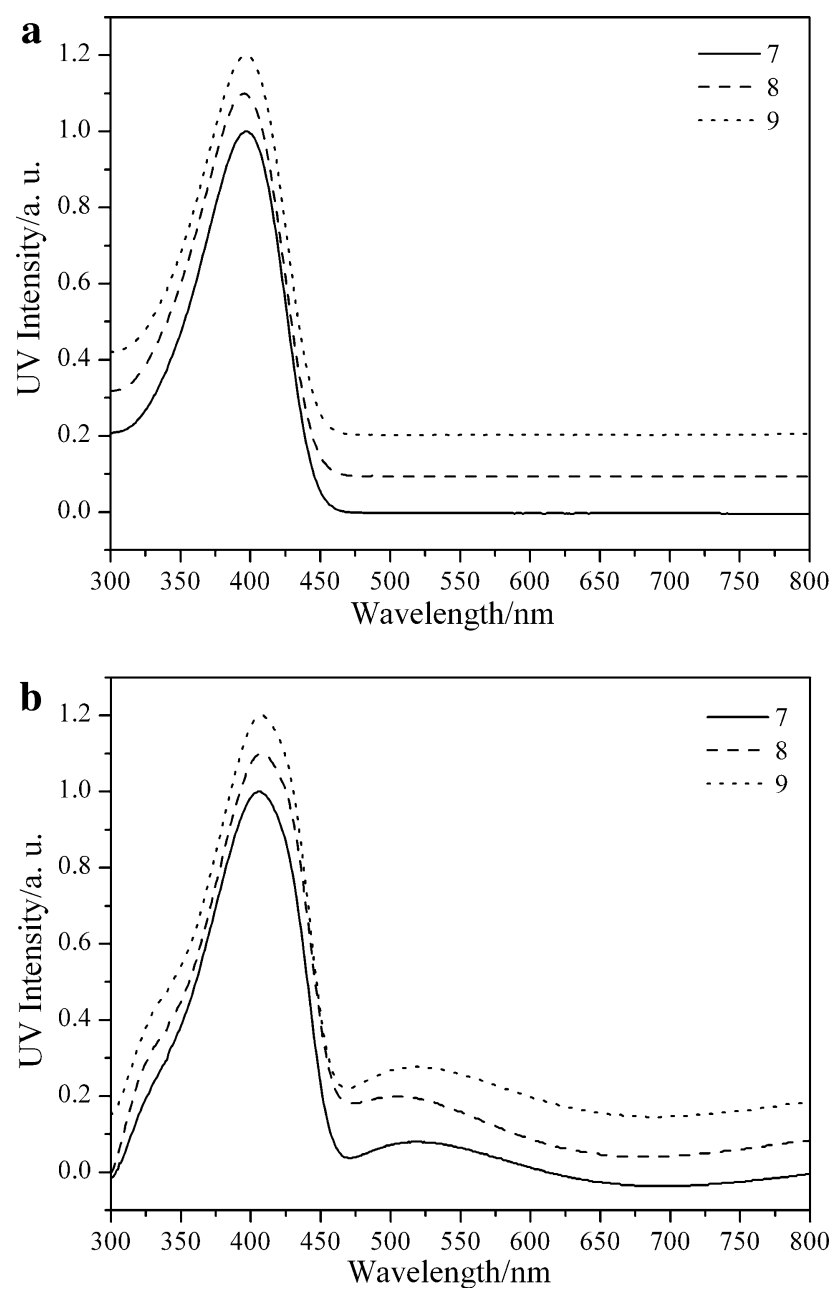

Fig. 2 UV-Vis spectra of 7, 8 , and $\mathbf{9}$ : a in $\mathrm{CHCl}_{3}$ solution, and $\mathbf{b}$ as thin film (the maxima at higher wavelengths stems from interference effects of the thin layer). For better visibility, spectra are shifted vertically

showed an absorption maximum at $397 \mathrm{~nm}$. This maximum is slightly red-shifted in comparison with a pure poly-(fluorene), e.g., poly-2,7-(9,9-dioctylfluorene) in chloroform $\left(\lambda_{\max }=385 \mathrm{~nm}\right)$ [29], because of the thiophene unit in the copolymer. The value varies between $386 \mathrm{~nm}$ for a poly-[(hexyl 2,5-thiophene-3-carboxylate)2,7-(9,9-dihexylfluorene)] (A) and $412 \mathrm{~nm}$ for poly-[(2,5thiophene)-2,7-(9,9-dihexylfluorene)] (B) [30].

The absorption of the polymers in thin films is redshifted by $10 \mathrm{~nm}\left(\lambda_{\max }=407 \mathrm{~nm}\right)$. This shift might be attributed to improved intermolecular $\pi-\pi$ interactions or planarization of the backbone in the film [31]. The additional broad peak found in all spectra is caused by interference fringes of the thin film. By casting thinner or thicker films this peak shifts or even completely vanishes. The optical band gaps, $E_{\mathrm{g}}$, of 7-9 were estimated from the onset of absorption of the UV-Vis spectrum of the polymer solution. Values of $E_{\mathrm{g}}=2.7 \mathrm{eV}$ for all polymers were

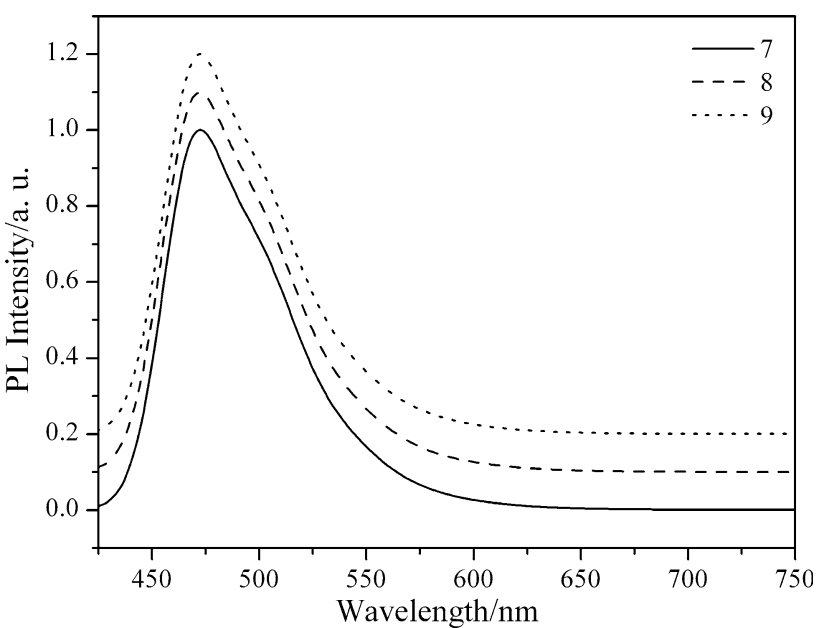

Fig. 3 Photoluminescence spectra of 7, 8, and 9 in $\mathrm{CHCl}_{3}$ solution (excitation wavelength $397 \mathrm{~nm}$ ). For better visibility, spectra are shifted vertically

obtained. These values are in good agreement with data published for polymers $\mathbf{A}$ and $\mathbf{B}$ by Pal et al. [30] and showed that the optical properties are almost unaffected by the side-chains.

Figure 3 shows the photoluminescence spectra of the chloroform solution. The PL emission spectra showed a maximum at $472 \mathrm{~nm}$ and a shoulder at around $500 \mathrm{~nm}$. The fluorescence quantum yields $(\Phi)$ of the polymers in chloroform were estimated by comparison with a quinine sulfate standard (ca. $1 \times 10^{-5} \mathrm{M}$ solution in $0.5 \mathrm{M} \mathrm{H}_{2} \mathrm{SO}_{4}$, $\left.\Phi_{\mathrm{St}}=0.55\right)$. The measurement was accomplished according to the literature [32]. All three polymers showed PL quantum yield of approximately 0.3 .

All UV-Vis absorption and PL emission maxima of the polymers are listed in Table 3, together with their optical band gaps and PL quantum efficiencies.

\section{Electrochemical properties}

Cyclic voltammograms (CVs), shown in Fig. 4, on dropcast polymer films were conducted in acetonitrile using a

Table 3 Optical data and fluorescence quantum yields (in $\mathrm{CHCl}_{3}$ solution) of 7-9

\begin{tabular}{|c|c|c|c|c|c|c|}
\hline \multicolumn{3}{|c|}{$\lambda_{\max }$ solution $(\mathrm{nm})$} & \multirow[t]{2}{*}{$\Phi$} & \multicolumn{2}{|c|}{$\lambda_{\max }$ film $(\mathrm{nm})$} & \multirow[t]{2}{*}{$E_{\mathrm{g}}^{\mathrm{b}}(\mathrm{eV})$} \\
\hline & Absorption & Emission $^{\mathrm{a}}$ & & Absorption & Emission $^{\mathrm{a}}$ & \\
\hline 7 & 397 & $472(502)$ & 0.28 & 407 & $474(500)$ & 2.7 \\
\hline 8 & 396 & $472(502)$ & 0.30 & 407 & 472 (499) & 2.7 \\
\hline 9 & 397 & $472(502)$ & 0.29 & 407 & 473 (499) & 2.7 \\
\hline
\end{tabular}

${ }^{a}$ Data in parentheses are wavelengths of shoulders

${ }^{\mathrm{b}} E_{\mathrm{g}}$ stands for the energy band gap estimated from the onset wavelength of the optical absorption 


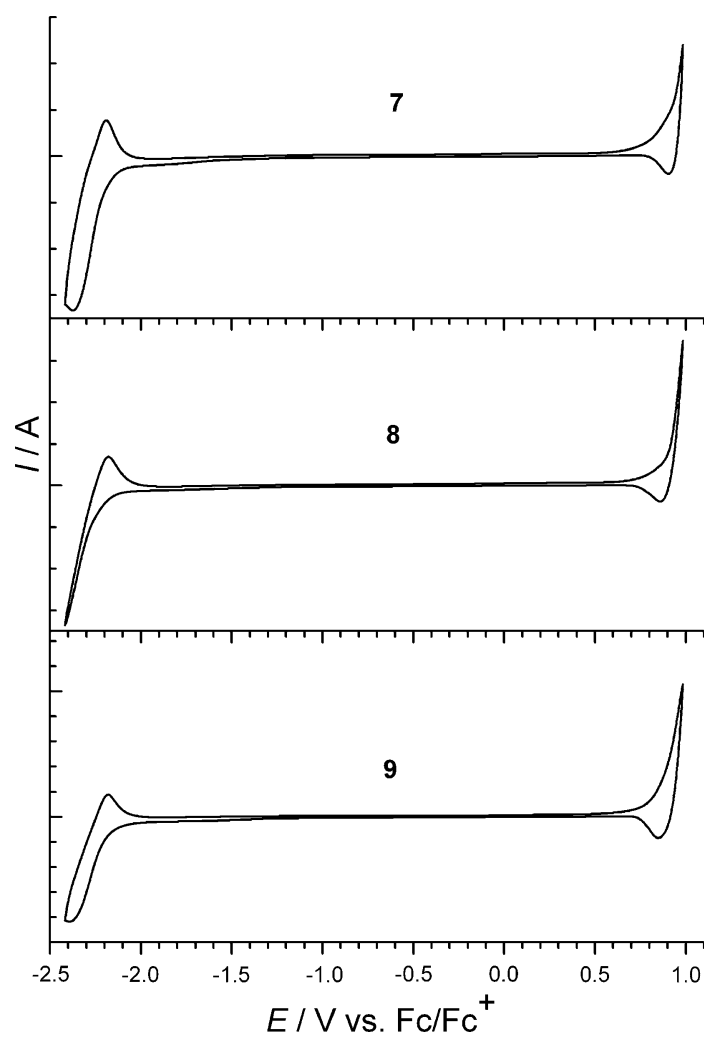

Fig. 4 Cyclic voltammograms of 7, 8, and 9 drop-coated on platinum plate electrodes in acetonitrile containing $0.1 \mathrm{M} n-\mathrm{Bu}_{4} \mathrm{NBF}_{4}$ with platinum wire as counterelectrode and $\mathrm{Ag} / \mathrm{Ag}^{+}$as reference electrode. Scan rate $100 \mathrm{mV} / \mathrm{s}$

platinum disk as working electrode, a platinum wire as counterelectrode, and $\mathrm{Ag} / \mathrm{Ag}^{+}$as reference electrode. Tetrabutylammonium tetrafluoroborate was used as supporting electrolyte and the ferrocene/ferrocenium $\left(\mathrm{Fc} / \mathrm{Fc}^{+}\right)$ couple as a calibrant [33]. The onset potentials of oxidation $\left(E_{\text {onset,ox }}\right)$ and reduction $\left(E_{\text {onset,red }}\right)$ were determined from the intersection of the two tangents drawn at the rising current and baseline charging current of the $\mathrm{CV}$ traces.

The ionization potentials $\left(I_{\mathrm{P}}\right)$ and electron affinities $\left(E_{\mathrm{A}}\right)$, which correlate to the HOMO and LUMO level of the polymers, were calculated from the onset of oxidation $\left(E_{\text {onset,ox }}\right)$ and reduction ( $\left.E_{\text {onset,red }}\right)$ according to the empirical relationship proposed by de Leeuw et al. [34].

$$
\begin{aligned}
& I_{\mathrm{P}}(\mathrm{HOMO})=-\left(E_{\text {onset }, \mathrm{ox}}+4.8\right)(\mathrm{eV}) \\
& E_{\mathrm{A}}(\mathrm{LUMO})=-\left(E_{\text {onset,red }}+4.8\right)(\mathrm{eV})
\end{aligned}
$$

The electrochemical band gaps $\left(E_{g}^{\mathrm{ec}}\right)$ derive from the difference between the ionization potential $\left(I_{\mathrm{P}}\right)$ and the electron affinity $\left(E_{\mathrm{A}}\right)[35,36]$.

$E_{g}^{\mathrm{ec}}=E_{\text {onset,ox }}-E_{\text {onset,red }}$.

The HOMO and LUMO levels for the different polymers are presented in Table 4 . The electrochemical
Table 4 Electrochemical properties and energy levels of polymers 7-9

\begin{tabular}{llllll}
\hline $\begin{array}{l}E_{\text {onset,ox }} \\
(\mathrm{eV})^{\mathrm{a}}\end{array}$ & $\begin{array}{l}E_{\text {onset,red }} \\
(\mathrm{eV})^{\mathrm{a}}\end{array}$ & $\begin{array}{l}\text { HOMO } \\
(\mathrm{eV})^{\mathrm{b}}\end{array}$ & $\begin{array}{l}\text { LUMO } \\
(\mathrm{eV})^{\mathrm{b}}\end{array}$ & $\begin{array}{l}E_{g}^{\text {ec }} \\
(\mathrm{eV})\end{array}$ \\
\hline $\mathbf{7}$ & 0.91 & -2.19 & -5.71 & -2.61 & 3.10 \\
$\mathbf{8}$ & 0.91 & -2.24 & -5.71 & -2.56 & 3.15 \\
$\mathbf{9}$ & 0.87 & -2.18 & -5.67 & -2.62 & 3.05 \\
\hline
\end{tabular}

a Versus $\mathrm{Fc} / \mathrm{Fc}^{+}$

b Versus vacuum, determined from the onset of oxidation/reduction

properties of $\mathbf{7 , 8}$, and $\mathbf{9}$ are very similar, thus the variations in the side-chains do not cause a noticeable difference of the electronic behavior between the polymers. For all three polymers, the HOMO and LUMO levels are approximately the same at around -5.7 and $-2.6 \mathrm{eV}$, respectively. The electrochemical band gap (approx. $3.1 \mathrm{eV}$ ) is significantly higher than the optical band gap; however, this phenomenon can be explained by an interface barrier between the polymer film and the electrode surface [36].

The HOMO levels are in good agreement with literature reports of a very similar polymer [30] bearing a hexyl carboxylate side-chain. However, the LUMO levels are significantly lower in our case, leading to a higher electrochemical band gap. This difference might be due to a different measurement setup, as we measured CVs of polymer films and not of a solution of the polymer in $\mathrm{CH}_{2} \mathrm{Cl}_{2}$.

\section{Conclusions}

In this contribution we have shown that introduction of glycol side-groups in the thiophene units of poly-fluorenealt-thiophene copolymers leads to polymers which are readily soluble in a variety of solvents ranging from apolar toluene to polar DMF. Especially 8 and 9 with longer ethylene glycol side-chains are already soluble in polar and protic solvents such as hot acetone, isopropyl alcohol, and ethanol. In addition, the optical properties and thermal stability are not affected by these side-groups and are comparable to other polyfluorene-thiophene polymers.

\section{Experimental}

All chemicals were purchased from commercial sources and used without further purification. $\mathrm{CH}_{2} \mathrm{Cl}_{2}$ was distilled over $\mathrm{CaH}_{2}$, THF was distilled over $\mathrm{Na}$ and subsequently over $\mathrm{K}$, and toluene was distilled over Na. All solvents were degassed with argon. All experiments were carried out under inert atmosphere in a glove box or using Schlenk techniques. 
${ }^{1} \mathrm{H}$ NMR and ${ }^{13} \mathrm{C}$ NMR spectra were recorded on a $300 \mathrm{MHz}$ Bruker Avance III spectrometer and were referenced to $\mathrm{Si}\left(\mathrm{CH}_{3}\right)_{4}$. Solvent residual peaks were used for referencing the NMR spectra to the corresponding values given in literature [37]. FTIR spectra were recorded with a PerkinElmer Spectrum One instrument (spectral range between 4,000 and $450 \mathrm{~cm}^{-1}$ ). All FTIR spectra of the samples were recorded in transmission mode (films on $\mathrm{KBr}$ discs). UV-Vis spectra were collected using a Shimadzu UV-1800 spectrometer. Fluorescence spectra were recorded on a Hitachi F-7000 fluorescence spectrometer equipped with a red-sensitive photomultiplier R 928 from Hamamatsu.

Molecular weights of the polymers were determined by GPC using the following arrangement: Merck Hitachi L6000 pump, a Polymer Standard Service precolumn, 2 PLgel separation columns $(5 \mu \mathrm{m}$ MIXED $\mathrm{C}$, $7.5 \times 300 \mathrm{~mm}$ ), and a Waters 401 differential refractometer detector. Polystyrene standards purchased from Polymer Standard Service were used for calibration. Combined DSC/TGA measurements were performed with a simultaneous thermal analyzer STA 449 C Jupiter from Netsch Gerätebau $\mathrm{GmbH}$ (crucibles: aluminum) at heating rate of $10{ }^{\circ} \mathrm{C} / \mathrm{min}$ in $\mathrm{He}$ flow $\left(50 \mathrm{~cm}^{3} / \mathrm{min}\right)$. DSC measurements were carried out on a PerkinElmer Pyris Diamond under nitrogen flow of $20 \mathrm{~cm}^{3} / \mathrm{min}$ and heating rate of $10^{\circ} \mathrm{C} / \mathrm{min}$. Glass-transition temperatures $\left(T_{\mathrm{g}}\right)$ from the second heating run were read as the midpoint of change in heat capacity. Cyclic voltammograms on dropcast polymer films were recorded using an Autolab PGSTAT128N potentiostat/galvanostat in a three-electrode cell with acetonitrile under argon gas protection with scan rate of $100 \mathrm{mV} / \mathrm{s}$. All measurements were carried out at room temperature $\left(25 \pm 2{ }^{\circ} \mathrm{C}\right)$. A platinum disk was used as working electrode, a platinum wire as counterelectrode, and $\mathrm{Ag} / \mathrm{Ag}^{+}$as reference electrode. Tetrabutylammonium tetrafluoroborate $\left(n-\mathrm{Bu}_{4} \mathrm{NBF}_{4}, 0.1 \mathrm{M}\right)$ was used as supporting electrolyte and the ferrocene/ferrocenium $\left(\mathrm{Fc} / \mathrm{Fc}^{+}\right)$ couple as a calibrant according to IUPAC recommendation [38].

\section{Synthesis}

Caution: For the preparative work, hazardous chemicals and solvents were used. Reactions must be carried out in a fume hood, and protective clothes and goggles must be used.

\section{2,5-Dibromothiophene-3-carboxylic acid (5)}

The acid $\mathbf{5}$ was prepared as described [25], but yielded 5 in only $41 \%$ yield compared with $84 \%$ given there. Obtained analytical data were identical to published values.
General procedure for compounds 1, 2, and 3 (modified from Ref. [25])

Substance 5 (1.00 g, $3.50 \mathrm{mmol}$ ) was dissolved in $100 \mathrm{~cm}^{3}$ dry $\mathrm{CH}_{2} \mathrm{Cl}_{2}, 0.6 \mathrm{~cm}^{3}$ oxalyl chloride $(6.96 \mathrm{mmol})$ was added, and the resulting mixture was stirred overnight at room temperature. The solvent was removed and dried under vacuum to give $\mathbf{6}$. The acid chloride was dissolved in $50 \mathrm{~cm}^{3}$ dry THF, and $0.8 \mathrm{~cm}^{3}$ pyridine $(10.49 \mathrm{mmol})$ followed by ethylene glycol monoethyl ether $(5.25 \mathrm{mmol})$ were added. The resulting mixture was stirred overnight. The reaction mixture was concentrated under reduced pressure, and the residue was partitioned between $\mathrm{CH}_{2} \mathrm{Cl}_{2}$ and $10 \%$ aqueous $\mathrm{HCl}$. The organic layer was dried over $\mathrm{Na}_{2} \mathrm{SO}_{4}$ and concentrated under reduced pressure to give a crude product, which was purified by column chromatography to afford the monomers as pale-yellow oils.

\section{2-Ethoxyethyl 2,5-dibromothiophene-3-carboxylate}

\section{$\left(1, \mathrm{C}_{9} \mathrm{H}_{10} \mathrm{Br}_{2} \mathrm{O}_{3} \mathrm{~S}\right)$}

2-Ethoxyethanol $\left(0.5 \mathrm{~cm}^{3}, 5.25 \mathrm{mmol}\right)$ was used as alcohol. Purification by column chromatography (cyclohexane/ ethyl acetate $=10 / 1)$ yielded $1(478 \mathrm{mg}, 38 \%) .{ }^{1} \mathrm{H}$ NMR $\left(\mathrm{CDCl}_{3}\right): \delta=7.37\left(\mathrm{~s}, 1 \mathrm{H}, \mathrm{H}^{4}\right), 4.41\left(\mathrm{t}, 2 \mathrm{H}, \mathrm{H}^{1^{\prime}}\right), 3.73(\mathrm{t}$, $\left.2 \mathrm{H}, \mathrm{H}^{2^{\prime}}\right), 3.56\left(\mathrm{q}, 2 \mathrm{H}, \mathrm{H}^{1^{\prime \prime}}\right), 1.22\left(\mathrm{t}, 3 \mathrm{H}, \mathrm{H}^{2^{\prime \prime}}\right) \mathrm{ppm} ;{ }^{13} \mathrm{C}$ $\operatorname{NMR}\left(\mathrm{CDCl}_{3}\right): \delta=160.9(\mathrm{C}=\mathrm{O}), 131.9\left(\mathrm{C}^{4}\right), 131.7\left(\mathrm{C}^{3}\right)$, $119.6\left(C^{2}\right), 111.5\left(C^{5}\right), 68.3\left(C^{2^{\prime}}\right), 66.8\left(C^{1^{\prime \prime}}\right), 64.5\left(C^{1^{\prime}}\right)$, $15.3\left(\mathrm{C}^{2^{\prime \prime}}\right) \mathrm{ppm}$.

\section{2-(2-Ethoxyethoxy)ethyl 2,5-dibromothiophene-3-}

carboxylate $\left(2, \mathrm{C}_{11} \mathrm{H}_{14} \mathrm{Br}_{2} \mathrm{O}_{4} \mathrm{~S}\right)$

Diethylene glycol monoethyl ether $\left(0.7 \mathrm{~cm}^{3}, 5.25 \mathrm{mmol}\right)$ was used as alcohol. Purification by column chromatography (cyclohexane/ethyl acetate $=5 / 1$ ) and flash chromatography (cyclohexane/ethyl acetate $=1 / 1$ ) yielded $2(508 \mathrm{mg}, 36 \%) .{ }^{1} \mathrm{H} \mathrm{NMR}\left(\mathrm{CDCl}_{3}\right): \delta=7.37\left(\mathrm{~s}, 1 \mathrm{H}, \mathrm{H}^{4}\right)$, $4.43\left(\mathrm{t}, 2 \mathrm{H}, \mathrm{H}^{1^{\prime}}\right), 3.81\left(\mathrm{t}, 2 \mathrm{H}, \mathrm{H}^{2^{\prime}}\right), 3.68\left(\mathrm{~m}, 2 \mathrm{H}, \mathrm{H}^{1^{\prime \prime}}\right), 3.60$ $\left(\mathrm{m}, 2 \mathrm{H}, \mathrm{H}^{2^{\prime \prime}}\right), 3.52\left(\mathrm{q}, 2 \mathrm{H}, \mathrm{H}^{1^{\prime \prime \prime}}\right), 1.22\left(\mathrm{t}, 3 \mathrm{H}, \mathrm{H}^{2^{\prime \prime \prime}}\right) \mathrm{ppm} ;{ }^{13} \mathrm{C}$ $\operatorname{NMR}\left(\mathrm{CDCl}_{3}\right): \delta=160.8(\mathrm{C}=\mathrm{O}), 131.9\left(\mathrm{C}^{4}\right), 131.7\left(\mathrm{C}^{3}\right)$, $119.6\left(\mathrm{C}^{2}\right), 111.5\left(\mathrm{C}^{5}\right), 70.9\left(\mathrm{C}^{1^{\prime \prime}}\right), 70.0\left(\mathrm{C}^{2^{\prime \prime}}\right), 69.1\left(\mathrm{C}^{2^{\prime}}\right)$, $66.9\left(\mathrm{C}^{1^{\prime \prime \prime}}\right), 64.4\left(\mathrm{C}^{1^{\prime}}\right), 15.3\left(\mathrm{C}^{2^{\prime \prime \prime}}\right) \mathrm{ppm}$.

2-[2-(2-Ethoxyethoxy)ethoxy]ethyl 2,5-dibromothiophene3-carboxylate $\left(3, \mathrm{C}_{13} \mathrm{H}_{18} \mathrm{Br}_{2} \mathrm{O}_{5} \mathrm{~S}\right)$

Triethylene glycol monoethyl ether $\left(0.9 \mathrm{~cm}^{3}, 5.25 \mathrm{mmol}\right)$ was used as alcohol. Purification by column chromatography (cyclohexane/ethyl acetate $=3 / 1$ ) and flash chromatography (cyclohexane/ethyl acetate $=1 / 3)$ yielded $3(539 \mathrm{mg}$, $35 \%) .{ }^{1} \mathrm{H} \mathrm{NMR}\left(\mathrm{CDCl}_{3}\right): \delta=7.36\left(\mathrm{~s}, 1 \mathrm{H}, \mathrm{H}^{4}\right), 4.13(\mathrm{t}, 2 \mathrm{H}$, $\left.\mathrm{H}^{1^{\prime}}\right), 3.79\left(\mathrm{t}, 2 \mathrm{H}, \mathrm{H}^{2^{\prime}}\right), 3.67-3.57\left(\mathrm{~m}, 8 \mathrm{H}, \mathrm{H}^{1^{\prime \prime}}, \mathrm{H}^{2^{\prime \prime}}, \mathrm{H}^{1^{\prime \prime \prime}}, \mathrm{H}^{2^{\prime \prime \prime}}\right)$, $3.51\left(\mathrm{q}, 2 \mathrm{H}, \mathrm{H}^{1^{\prime \prime \prime \prime}}\right), 1.20\left(\mathrm{t}, 3 \mathrm{H}, \mathrm{H}^{2^{\prime \prime \prime \prime}}\right) \mathrm{ppm} ;{ }^{13} \mathrm{C} \mathrm{NMR}$ $\left(\mathrm{CDCl}_{3}\right): \delta=160.8(\mathrm{C}=\mathrm{O}), 131.9\left(\mathrm{C}^{4}\right), 131.7\left(\mathrm{C}^{3}\right), 119.6$ $\left(\mathrm{C}^{2}\right), 111.5\left(\mathrm{C}^{5}\right), 70.9-70.8\left(\mathrm{C}^{1^{\prime \prime}}, \mathrm{C}^{2^{\prime \prime}}, \mathrm{C}^{1^{\prime \prime \prime}}\right), 70.0-69.1$ $\left(\mathrm{C}^{2^{\prime}}, \mathrm{C}^{2^{\prime \prime \prime}}\right), 66.9\left(\mathrm{C}^{1^{\prime \prime \prime \prime}}\right), 64.4\left(\mathrm{C}^{1^{\prime}}\right), 15.3\left(\mathrm{C}^{2^{\prime \prime \prime \prime}}\right) \mathrm{ppm}$. 


\section{General procedure: Suzuki coupling polymerization}

The phase transfer catalyst Aliquat $336(0.1 \mathrm{eq})$ was dissolved in a mixture of $1.7 \mathrm{~cm}^{3} 2 \mathrm{M}$ aqueous sodium carbonate $(3.46 \mathrm{mmol})$ and $8 \mathrm{~cm}^{3}$ anhydrous toluene. The solution was degassed for $30 \mathrm{~min}$. Substance 10 (1.0 eq) and 2,5-dibromothiophene 1-3 (1.0 eq) were added. Tetrakis(triphenylphosphine)palladium $(0.01 \mathrm{eq})$ was added to the mixture in argon atmosphere. The reaction mixture was stirred and heated to $85{ }^{\circ} \mathrm{C}$ for $48 \mathrm{~h}$. An excess of $\mathbf{1 0}$ ( $0.01 \mathrm{eq})$ and bromobenzene $(0.1 \mathrm{eq})$ were added for endcapping. After further stirring and heating for $12 \mathrm{~h}$, the reaction mixture was cooled to room temperature and added slowly to a vigorously stirred mixture consisting of $100 \mathrm{~cm}^{3}$ methanol and $5.6 \mathrm{~cm}^{3} 1 \mathrm{~N}$ aqueous $\mathrm{HCl}$. The polymer was collected by filtration and purified by reprecipitation from methanol.

\section{Poly-[9,9-dioctylfluorene-alt-(2-ethoxyethyl thiophene-3-}

carboxylate $)]\left(7,\left(\mathrm{C}_{38} \mathrm{H}_{50} \mathrm{O}_{3} \mathrm{~S}\right)_{n}\right)$

Polymer 7 was synthesized using the general Suzuki coupling procedure starting from $150.0 \mathrm{mg} \mathbf{1}(0.42 \mathrm{mmol})$ as thiophene monomer. A part of the polymer was further purified by Soxhlet extraction in acetone for 2 days to yield a green solid. Yield (before Soxhlet extraction) $181 \mathrm{mg}$ (73\%); ${ }^{1} \mathrm{H}$ NMR $\left(\mathrm{CDCl}_{3}\right): \delta=7.84-7.55(\mathrm{~m}, 7 \mathrm{H}$, aromatic), $4.38\left(\mathrm{~s}, 2 \mathrm{H}, \mathrm{H}^{1^{\prime}}\right), 3.63\left(\mathrm{~s}, 2 \mathrm{H}, \mathrm{H}^{2^{\prime}}\right), 3.50(\mathrm{q}, 2 \mathrm{H}$, $\left.\mathrm{H}^{1^{\prime \prime}}\right), 2.05\left(\mathrm{~s}, 4 \mathrm{H}, \mathrm{H}^{\text {oct1 }}\right), 1.24-1.12\left(\mathrm{~m}, 23 \mathrm{H}, \mathrm{H}^{2^{\prime \prime}}, \mathrm{H}^{\mathrm{oct} 2-6}\right)$, $0.81\left(\mathrm{~s}, 10 \mathrm{H}, \mathrm{H}^{\text {oct7 }}, \mathrm{H}^{\text {oct8 }}\right) \mathrm{ppm}$; IR (KBr): $\bar{v}=2,954(\mathrm{~s})$, 2,926 (s), 2,854 (s), 1,724 (s), 1,608 (w), 1,538 (w), 1,463 (m), 1,419 (w), 1,377 (w), 1,261 (m), 1,203 (m), 1,124 (m), $882(\mathrm{w}), 819(\mathrm{~m}), 801(\mathrm{~m}), 522(\mathrm{w}) \mathrm{cm}^{-1}$.

\section{Poly-[9,9-dioctylfluorene-alt-[2-(2-ethoxyethoxy)ethyl}

thiophene-3-carboxylate]] $\left(\mathbf{8},\left(\mathrm{C}_{40} \mathrm{H}_{54} \mathrm{O}_{4} \mathrm{~S}\right)_{n}\right)$

Polymer 8 was synthesized using the general Suzuki coupling procedure starting from $219.4 \mathrm{mg} 2(0.55 \mathrm{mmol})$ as thiophene to yield a light-green solid. Yield $265 \mathrm{mg}$ $(76 \%) ;{ }^{1} \mathrm{H}$ NMR $\left(\mathrm{CDCl}_{3}\right): \delta=7.84-7.55(\mathrm{~m}, 7 \mathrm{H}$, aromatic), $4.39\left(\mathrm{~s}, 2 \mathrm{H}, \mathrm{H}^{1^{\prime}}\right), 3.71\left(\mathrm{~s}, 2 \mathrm{H}, \mathrm{H}^{2^{\prime}}\right), 3.59(\mathrm{~m}, 4 \mathrm{H}$, $\left.\mathrm{H}^{1^{\prime \prime}}, \mathrm{H}^{2^{\prime \prime}}\right), 3.52\left(\mathrm{q}, 2 \mathrm{H}, \mathrm{H}^{1^{\prime \prime \prime}}\right), 2.05\left(\mathrm{~s}, 4 \mathrm{H}, \mathrm{H}^{\text {oct } 1}\right), 1.24-1.12$ $\left(\mathrm{m}, 23 \mathrm{H}, \mathrm{H}^{2^{\prime \prime \prime}}, \mathrm{H}^{\text {oct2-6 }}\right), 0.81\left(\mathrm{~s}, 10 \mathrm{H}, \mathrm{H}^{\text {oct7 }}, \mathrm{H}^{\text {oct8 }}\right) \mathrm{ppm}$; IR $(\mathrm{KBr}): \bar{v}=2,954$ (s), 2,926 (s), 2,854 (s), 1,724 (s), 1,608 (w), 1,538 (w), 1,463 (m), 1,419 (w), 1,376 (w), 1,350 (w), 1,263 (m), 1,204 (m), 1,124 (m), 1,018 (w), 820 (m), 752 (m) $\mathrm{cm}^{-1}$.

Poly-[9,9-dioctylfluorene-alt-[2-[2-(2-ethoxyethoxy)ethoxy]ethyl thiophene-3-carboxylate ] $\left(9,\left(\mathrm{C}_{42} \mathrm{H}_{58} \mathrm{O}_{5} \mathrm{~S}\right)_{n}\right)$

Polymer 9 was synthesized using the general Suzuki coupling procedure starting from $237.7 \mathrm{mg} 3(0.53 \mathrm{mmol})$ as thiophene to yield a light-green solid. Yield $332 \mathrm{mg}$ (91\%); ${ }^{1} \mathrm{H}$ NMR $\left(\mathrm{CDCl}_{3}\right): \delta=7.84-7.54(\mathrm{~m}, 7 \mathrm{H}$, aromatic), $4.38\left(\mathrm{~s}, 2 \mathrm{H}, \mathrm{H}^{1^{\prime}}\right), 3.70-3.58\left(\mathrm{~m}, 10 \mathrm{H}, \mathrm{H}^{2^{\prime}}, \mathrm{H}^{1^{\prime \prime}}, \mathrm{H}^{2^{\prime \prime}}\right.$,
$\left.\mathrm{H}^{1^{\prime \prime \prime}}, \mathrm{H}^{2^{\prime \prime \prime}}\right), 3.51\left(\mathrm{q}, 2 \mathrm{H}, \mathrm{H}^{1^{\prime \prime \prime \prime}}\right), 2.05\left(\mathrm{~s}, 4 \mathrm{H}, \mathrm{H}^{\text {oct1 }}\right), 1.26-1.12$ $\left(\mathrm{m}, 23 \mathrm{H}, \mathrm{H}^{2^{\prime \prime \prime \prime}}, \mathrm{H}^{\text {oct2-6 }}\right), 0.81\left(\mathrm{~s}, 10 \mathrm{H}, \mathrm{H}^{\text {oct7 }}, \mathrm{H}^{\text {oct8 }}\right)$ ppm; IR $(\mathrm{KBr}): \bar{v}=2,954(\mathrm{~s}), 2,925$ (s), 2,853 (s), 1,723 (s), 1,609 (w), 1,538 (w), 1,463 (m), 1,376 (w), 1,350 (w), 1,264 (m), 1,204 (m), 1,125 (m), 1,038 (w), $940(\mathrm{w}), 820(\mathrm{~m}), 777(\mathrm{w})$, $756(w) \mathrm{cm}^{-1}$.

Acknowledgments The authors thank the Austrian Science Fund (FWF): N903-NAN within the Austrian NanoInitiative (Research Project Cluster 900), the Christian Doppler Research Association (CDG), and the Federal Ministry for Economy, Family and Youth (BMWFJ) for financial support.

Open Access This article is distributed under the terms of the Creative Commons Attribution Noncommercial License which permits any noncommercial use, distribution, and reproduction in any medium, provided the original author(s) and source are credited.

\section{References}

1. Roncali J (2007) Macromol Rapid Commun 28:1761

2. Dodabalapur A (2006) Mater Today 9:24

3. Grimsdale AC, Chan KL, Martin RE, Jokisz PG, Holmes AB (2009) Chem Rev 109:897

4. Akcelrud L (2003) Prog Polym Sci 28:875

5. Allard S, Forster M, Souharce B, Thiem H, Scherf U (2008) Angew Chem Int Ed 47:4070

6. Thomas SW, Joly GD, Swager TM (2007) Chem Rev 107:1339

7. Dennler G, Scharber MC, Brabec CJ (2009) Adv Mater 21:1323

8. Cheng Y-J, Yang S-H, Hsu C-S (2009) Chem Rev 109:5868

9. Scherf U, List EJW (2002) Adv Mater 14:477

10. Zhao Q, Liu S-J, Huang W (2009) Macromol Chem Phys 210:1580

11. Neher D (2001) Macromol Rapid Commun 22:1365

12. Scherf U, Neher D (2008) In: Advances in polymer science, Vol 212, Springer, Berlin

13. Tsoi WC, Charas A, Cadby AJ, Khalil G, Adawi AM, Iraqi A, Hunt B, Morgado J, Lidzey DG (2008) Adv Funct Mater 18:600

14. Inganäs $\mathrm{O}$, Zhang $\mathrm{F}$, Andersson MR (2009) Acc Chem Res 42:1731

15. Leclerc M (2001) J Polym Sci A Polym Chem 39:2867

16. Kappaun S, Horner S, Kelterer A-M, Waich K, Grasse F, Graf M, Romaner L, Niedermair F, Müllen K, Grimsdale AC, Saf R, List EJW, Zojer E, Slugovc C (2008) Macromol Chem Phys 209:2122

17. Winfield JM, Van Vooren A, Park M-J, Hwang D-H, Cornil J, Kim J-S, Friend RH (2009) J Chem Phys 131:035104

18. Abbel R, Schenning APHJ, Meijer EW (2009) J Polym Sci A Polym Chem 47:4215

19. Inganäs O, Svensson M, Zhang F, Gadisa A, Persson NK, Wang X, Andersson MR (2004) Appl Phys A 79:31

20. Levermore PA, Jin R, Wang X, de Mello JC, Bradley DDC (2009) Adv Funct Mater 19:950

21. McNeill CR, Greenham NC (2009) Adv Mater 21:3840

22. Sakamoto J, Rehahn M, Wegner G, Schlüter AD (2009) Macromol Rapid Commun 30:653

23. Burrows HD, Tapia MJ, Fonseca SM, Valente AJM, Lobo VMM, Justino LLG, Qiu S, Pradhan S, Scherf U, Chattopadhyay N, Knaapila M, Garamus VM (2009) ACS Appl Mater Interf 1:864

24. Knaapila M, Almásy L, Garamus VM, Pearson C, Pradhan S, Petty MC, Scherf U, Burrows H-D, Monkman AP (2006) J Phys Chem B 110:10248 
25. Kim D-S, Ahn KH (2008) J Org Chem 73:6831

26. Lim E, Jung B-J, Shim H-K (2003) Macromolecules 36:4288

27. Snyder LR (1978) J Chromatogr Sci 16:223

28. Louisiana State University Macromolecular Studies Group, polarity index. http://macro.lsu.edu/howto/solvents/Polarity\%20 index.htm. Accessed December 2009

29. Wang R, Wang W-Z, Yang G-Z, Liu T, Yu J, Jiang Y (2008) J Polym Sci A Polym Chem 46:790

30. Pal B, Yen W-C, Yang J-S, Su W-F (2007) Macromolecules 40:8189

31. Surin M, Sonar P, Grimsdale AC, Müllen K, Lazzaroni R, Leclère $P$ (2005) Adv Funct Mater 15:1426

32. Horiba JY, A guide to recording fluorescence quantum yields. http://www.horiba.com/fileadmin/uploads/Scientific/Documents/ Fluorescence/quantumyieldstrad.pdf. Accessed October 2009
33. Pommerehne J, Vestweber H, Guss W, Mahrt RF, Bässler H, Porsch M, Daub J (1995) Adv Mater 7:551

34. De Leeuw DM, Simenon MMJ, Brown AR, Einerhand REF (1997) Synth Met 87:53

35. Pei J, Yu W-L, Huang W, Heeger AJ (2000) Macromolecules 33:2462

36. Chen Z-K, Huang W, Wang L-H, Kang E-T, Chen BJ, Lee CS, Lee ST (2000) Macromolecules 33:9015

37. Gottlieb HE, Kotlyar V, Nudelman A (1997) J Org Chem 62:7512

38. Gritzner G (1990) Pure Appl Chem 62:1839 